\title{
The relationship between metabolic syndrome and increased risk of Barrett's esophagus: An Updated systematic review and meta-analysis
}

Mohammad Karimian

Ilam University of Medical Sciences

Majid Salamati

Ilam University of Medical Sciences

Milad Azami ( $\sim$ Milad98azami@gmail.com)

Ilam University of Medical Sciences https://orcid.org/0000-0002-4509-5520

\section{Research article}

Keywords: Metabolic Syndrome, Barrett's Esophagus, Meta-Analysis

Posted Date: October 9th, 2019

DOI: https://doi.org/10.21203/rs.2.15792/v1

License: () (i) This work is licensed under a Creative Commons Attribution 4.0 International License. Read Full License

Version of Record: A version of this preprint was published at BMC Gastroenterology on May 6th, 2020. See the published version at https://doi.org/10.1186/s12876-020-01267-2. 


\section{Abstract}

Background: The relationship between MetS and Barrett's esophagus (BE) is still a challenging issue, and inconsistent results have been reported in different studies. Therefore, this study was conducted to determine the relationship between MetS and BE.

Methods: In this study, we followed the MOOSE protocol and the PRISMA guidelines for reporting the results. All study steps were performed independently by two authors. If necessary, the dispute was resolved by consultation with a third author. The search strategy is designed to find published studies.

Comprehensive search was done in the following biomedical databases until July 2019: Cochrane Library, PubMed/Medline, Web of Science, Science Direct, EMBASE, Scopus, CINAHL, EBSCO, and Google Scholar search engine. All analyses were performed using Comprehensive Meta-Analysis Software Ver.2, while p-value lower than 0.05 was considered significant.

Results: In 14 studies with a sample size of 108416 , MetS significantly increased the risk of $B E(O R=1.315 ; 95 \%$ Cl: $1.110-1.558 ; P<0.001 ;$ Heterogeneity: I 2 = 81.55; $P<0.001)$. Sensitivity analysis by omitting one study showed that overall estimates are still robust. Subgroup analysis was significant for continent $(P<0.001)$ and MetS diagnostic criteria $(P=0.043)$, but was not significant for variables of study type $(P=0.899)$, study setting $(P=0.115)$, control groups $(P=0.671)$ and quality of studies $(P=0.603)$. The Begg $(P=0.912)$ and Egger's $(P=0.094)$ tests were not significant; therefore, the publication bias did not play a role in the results.

Conclusion: MetS increases the risk of BE compared to control groups. Future studies should examine whether treatment for metabolic syndrome reduces the risk of $\mathrm{BE}$.

\section{Introduction}

Barrett's esophagus (BE) is often defined as a change in any length of the epithelium of the esophagus that can be diagnosed as columnar-type mucosa in endoscopy and is confirmed as intestinal metaplasia through esophageal biopsy (1). BE is considered a precancerous condition that is closely related to esophageal cancer, especially esophageal adenocarcinoma (EAC) (2). The prevalence of BE and the incidence of EAC has increased in Western countries (3). The most important risk factor for BE is gastroesophageal reflux disease (GERD), while other risk factors include male gender, hiatus hernia, and smoking (4$5)$.

Metabolic syndrome (MetS) is a complex disorder that includes central obesity, hypertension (HTN), hyperglycemia, hypertriglyceridemia and high-density lipoprotein cholesterol (HDL-C). In addition to being related to cardiovascular disease, diabetes, and polycystic ovary syndrome, MetS and its elements are also linked with various gastrointestinal diseases and abnormal liver function (6-7). This disease affects one-fifth of the population in developed countries and its incidence increases with age. The prevalence of MetS is approximately $24 \%$ in the United States, $12 \%$ in Europe and $10-40 \%$ in most Asian countries (8-9).

Based on recent evidence, the prevalence of both diseases is increasing rapidly. Hence, the relationship between MetS and BE has been hypothesized (8-9). Most studies investigating the relationship between obesity and BE have shown that obesity can lead to a significant increase in the risk of BE (4-5).

Although numerous studies have shown that any of the MetS criteria (i.e., abdominal obesity, hyperglycemia, and hypertension) can be a risk factor for BE, the relationship between MetS and BE is still a challenging issue, and inconsistent results have been reported in different studies (10-20).

Meta-analysis is a subset of systematic reviews. The systematic review seeks to collect empirical evidence that meets the predicted eligibility criteria to answer a specific research question. Meta-analysis results may include a more accurate estimate of the impact of treatment or risk factors for disease or other outcomes by combining individual studies (21-22). Therefore, this study was conducted to determine the relationship between MetS and BE.

\section{Method}

\subsection{Study Protocol}

In this study, we followed the Meta-analyses Of Observational Studies in Epidemiology (MOOSE) (23) protocol and the Preferred Reporting Items for Systematic Reviews and Meta-analysis (PRISMA) (S1 file) (24) guidelines for reporting the results. All study steps were performed independently by two authors. If necessary, the dispute was resolved by consultation with a third author.

\subsection{Search strategy}

The search strategy is designed to find published studies. Comprehensive search was done in the following biomedical databases until July 2019 :

Cochrane Library (Cochrane Database of Systematic Reviews - CDSR), PubMed/Medline, Web of Science (ISI), Science Direct, EMBASE, Scopus, CINAHL, EBSCO, and Google Scholar search engine.

There were no restrictions based on language or release date. The search was done using the following MeSH keywords: "Metabolic Syndrome"[Mesh], "Gastroesophageal Reflux”[Mesh], “Esophagitis”[Mesh], “Barrett Esophagus”[Mesh], and “Esophagus”[Mesh].

Combined search in PubMed was done as follows: ((“"Metabolic Syndrome”[Mesh]) AND "Gastroesophageal Reflux"[Mesh]) OR ("Esophagus”[Mesh] OR "Barrett Esophagus"[Mesh])) OR “Esophagitis"[Mesh]. Reference lists were screened from all relevant studies to find potential articles.

2.3. Study selection

Page 2/11 
Two authors (M.A, M.K, or M.S) screened the titles and abstracts independently and then reviewed the full text of the retrieved studies for eligibility based on the defined criteria. If necessary, the dispute was resolved by consultation with a third reviewer.

\subsection{Inclusion and exclusion criteria}

This study included prospective and retrospective cohort studies (case-control and cross-sectional studies). The language of the published articles was considered in all languages and no historical restrictions were placed on the search. Google Translate and a relevant language teacher were referred to for the translation of non-English texts if necessary. The exclusion criteria were: duplicate studies, studies that did not differentiate BE from GERD, being irrelevant; low quality in qualitative assessment; case studies, review articles, letters to the editor without quantitative data and theses.

\subsection{Data Extraction}

If available, the following data were extracted according to the aim of the study: first author's name, year of publication, year of review, country/continent, in formation about the study population (specific groups, population size for the entire sample, case, control, male and female in each case and control groups), number of BE positive patients in each case and control, study design, setting, adjusted or unadjusted odds ratio $\left(\mathrm{OR}_{\mathrm{s}}\right)$ or relative risk $\left(\mathrm{RR}_{\mathrm{s}}\right)$, diagnostic criteria for MetS, and quality assessment score.

\subsection{Quality Assessment}

Methodological quality was assessed using the Newcastle-Ottawa Quality Assessment Scale (25) for both cohort or case-control studies based on study design and its adapted type for cross-sectional studies. The scale is based on three categories: 1 . sample selection (4 points), 2. Comparability of groups (2 points), and 3. Level of exposure/outcome (3 points). Therefore, a maximum of 9 points can be attained. The different levels of methodological quality were defined as follows: $0-4$ points: low quality, 5-7 points: average quality, and 8-9 points: high quality.

\subsection{Statistical analysis}

We combined the studies with the odds ratio $\left(\mathrm{OR}_{\mathrm{s}}\right)$ index and $95 \%$ confidence interval. In studies that did not report $O \mathrm{R}_{\mathrm{s}}$ and $95 \%$ confidence intervals, we calculated them based on the total sample size of each group as well as the number of MetS positive cases in each of the case (BE) and control (Non-BE) groups. $\mathrm{I}^{2}$ index and Q test were used to evaluate the heterogeneity of studies. Cut-off points for $\mathrm{I}^{2}$ were defined as $0-24 \%, 25-49 \%, 50-74 \%$, and $75-100 \%$ for low, medium, high and very high, respectively $(26,27)$. We performed sensitivity analysis for the stability of pooled estimation through omission of only one study. To find out the cause of the heterogeneity, we performed subgroup analysis based on study type, setting, control groups, MetS diagnostic criteria, and continent. Meta-regression analysis was also performed based on the year of publication. Funnel plot and Begg and Egger's tests were used to assess publication bias $(28,29)$. All analyses were performed using Comprehensive Meta-Analysis Software Ver.2, while p-value lower than 0.05 was considered statistically significant.

\section{Results}

3.1. Search results and study characteristics

The electronic search has identified 2510 studies. A total of 2492 studies were excluded based on the review of title and abstract. Another 7 articles were excluded because they did not meet our inclusion criteria. Eleven articles met our inclusion criteria and were included in the meta-analysis (the studies of Drahos J, 2015 [13], Leggett CL, 2013 [14], and Thrift AP, 2015 [15] each were considered as two studies, since they reported the data in two different populations) (Figure 1). The characteristics of the studies are shown in Table 1.

3.2. Meta-analysis of MetS and increased risk BE and sensitivity analysis

In 14 studies with a sample size of 108416 , MetS significantly increased the risk of BE (OR = 1.315; 95\% Cl: $1.110-1.558 ; P<0.001 ;$ Heterogeneity: $\left.\right|^{2}=81.55$; $\mathrm{P}<0.001$ ) (Figure 2-A). Sensitivity analysis by omitting one study showed that overall estimates are still robust (Figure $B-2)$.

3.3. MetS subgroup analysis and increased risk of BE

Subgroup analysis was significant for continent $(P<0.001)$ and MetS diagnostic criteria $(P=0.043)$, but was not significant for variables of study type $(P=$ 0.899), study setting $(P=0.115)$, control groups $(P=0.671)$ and quality of studies $(P=0.603)$ (Figure 3$)$.

\subsection{Meta-regression and publication bias}

The meta-regression model based on year of publication of articles was not significant for the relationship between MetS and BE (meta-regression coefficient: $0.041 ; 95 \% \mathrm{Cl}-0.017$ to $0.101 ; \mathrm{P}=0.167$ ) (Figure $4-\mathrm{A})$.

The publication bias is shown as a funnel plot, and the Begg $(P=0.912)$ and Egger's $(P=0.094)$ tests were not significant; therefore, the publication bias did not play a role in the results (Figure $B-4)$.

\section{Discussion}

The present study is an update to the previous meta-analysis in 2016 (30), which found a significant relationship between MetS and BE (OR = 1.23; $95 \%$ Cl: $1.03-1.47 ; P=0.024$ ) by combining eight studies. In the present study, a combination of 14 studies showed that MetS significantly increases the risk of $B E$ 
$(\mathrm{OR}=1.315 ; 95 \% \mathrm{Cl}: 1.110-1.558 ; \mathrm{P}<0.001)$. The strengths of the present study were the increase in the number of studies involved in meta-analysis and finding a more accurate relationship and a stronger level of significance for the relationship between MetS and BE. The causes of heterogeneity between the studies include the continent $(P<0.001)$ and MetS diagnostic criteria $(P=0.043)$.

In a systematic review and meta-analysis, age, male gender, smoking, longer BE segment, and low-grade dysplasia were risk factors for BE progression (31). However, other studies continue to suggest that GERD is the strongest risk factor for BE. Moreover, the use of statin alone or in combination with aspirin as well as proton pump inhibitors (PPI) significantly reduced the risk of $\mathrm{BE}(31,32)$. In another meta-analysis, infection with Helicobacter pylori ( $\mathrm{H}$. pylori) also reduced the risk of $B E(33)$.

$\mathrm{BE}$ is a precancerous condition for the EAC (2). EAC is the most common type of esophageal cancer in the United States. Although GERD, smoking, and obesity have been suggested as associated risk factors, the major predictor of progression from non-dysplastic BE to esophageal adenocarcinoma is the presence of dysplastic changes in esophageal histology (34). Clinical guidelines recommend that periodic endoscopy be used to diagnose dysplasia and primary cancer in patients with $\mathrm{BE}$, and this monitoring for BE patients may improve the prognosis of EAC (35).

A meta-analysis confirmed the conclusion that central adiposity can be strongly associated with esophageal inflammation and reflux (36). Studies have shown that visceral obesity, as the main criterion for MetS, can increase the transient lower esophageal sphincter relaxation, the incidence of hiatal hernia, or even intra-abdominal pressure and acid reflux $(37,38)$.

In studies about hypertriglyceridemia, even after adjusting for obesity and other metabolic factors, it is associated with increased risk of BE (8). Impairment of lipid metabolism is common in MetS. Abdominal obesity is a known risk factor associated with MetS. MetS is the result of obesity-related hormonal and systemic inflammatory changes and is associated with multi-system cancers in humans. There are several possible explanations for this relationship. First, insulin resistance and fatty liver may be responsible for elevated serum triglyceride (TG) levels, since fatty liver is significantly associated with fasting glucose and TG levels (39). Hypertriglyceridemia is also associated with increased insulin resistance (40). Second, since H. pylori infection is known to be a protective factor for EE $(41,42)$ and chronic $H$. pylori infections can alter serum lipid profile, such as increasing total cholesterol and TG $(43,44)$, the increased serum TG levels can only be a side effect associated with $\mathrm{H}$. pylori infection.

In other studies, the association between HTN and hypercholesterolemia (as MetS components) has also been demonstrated (45). Atherosclerosis is recognized as an important factor for the development of HTN. In previous studies, atherosclerosis was associated with a high incidence of hiatal hernia. Loss of flexibility in the phrenoesophageal ligament in patients with arthrosclerosis and HTN is one of the causes of increased incidence of hiatal hernia (46).

This study has several strengths, including the fact that we used a comprehensive, concurrent search strategy to maximize the ability to identify all relevant literature. All stages of the research were conducted by two researchers independently, and the differences were resolved by discussion. We contacted the authors of the studies to obtain additional data. Based on the available data, we were able to identify some of the causes of heterogeneity between the studies.

One of the limitations of the present study is the high heterogeneity between the studies, though we attempted to discover the causes of heterogeneity through subgroup analysis. In addition, most studies were conducted in the United States, which may influence the results.

\section{Conclusion}

MetS increases the risk of BE compared to control groups. Future studies should examine whether treatment for metabolic syndrome reduces the risk of BE and EA.

\section{Abbreviations}

BE Barrett's esophagus

EAC Esophageal adenocarcinoma

GERD Gastroesophageal reflux disease

MetS Metabolic syndrome

HTN Hypertension

HDL-C High-density lipoprotein cholesterol

MOOSE Meta-analyses Of Observational Studies in Epidemiology

PRISMA Systematic Reviews and Meta-analysis

OR Odds ratio

Cl Confidence interval

\section{Declarations}


MA, MS, and MK acquired the data. MA and MK analyzed and interpreted the data. MA drafted the manuscript; MA, MS, and MK critically revised the manuscript for important intellectual content. MK supervised the study.

Funding

This study was funded by the llam University of Medical sciences.

Availability of data and materials

Not applicable.

Ethics approval and consent to participate

Not applicable.

Consent for publication

Not applicable.

Competing interests

We declare no competing interests.

\section{References}

1. Wang KK, Sampliner RE. Practice Parameters Committee of the American College of Gastroenterology. Updated guidelines 2008 for the diagnosis, surveillance and therapy of Barrett's esophagus. Am J Gastroenterol. 2008;103(3):788-797.

2. de Jonge PJ, van Blankenstein M, Grady WM, Kuipers EJ. Barrett's oesophagus: epidemiology, cancer risk and implications for management. Gut 2014; 63:191-202.

3. van Soest EM, Dieleman JP, Siersema PD, et al. Increasing incidence of Barrett's oesophagus in the general population. Gut. 2005;54(8):1062-1066.

4. Shiota S, Singh S, Anshasi A, El-Serag HB. Prevalence of Barrett's Esophagus in Asian Countries: A Systematic Review and Meta-analysis. Clin Gastroenterol Hepatol. 2015;13(11):1907-18.

5. Singh S, Sharma AN, Murad MH, Buttar NS, El-Serag HB, Katzka DA, et al. Central adiposity is associated with increased risk of esophageal inflammation, metaplasia, and adenocarcinoma: a systematic review and meta-analysis. Clin Gastroenterol Hepatol 2013; 11:1399.e7-1412.e7.

6. Otaghi M, Azami M, Khorshidi A, Borji M, Tardeh Z. The association between metabolic syndrome and polycystic ovary syndrome: A systematic review and meta-analysis. Diabetes Metab Syndr. 2019;13(2):1481-1489. doi: 10.1016/j.dsx.2019.01.002. Epub 2019 Jan 21.

7. Cooper-DeHoff RM, Pepine CJ. Metabolic syndrome and cardiovascular disease: challenges and opportunities. Clin Cardiol. 2007;30(12):593-7. doi: 10.1002/clc.7. PubMed PMID: 17607758; PubMed Central PMCID: PMC2794411.

8. Ryan AM, Healy LA, Power DG, Byrne M, Murphy S, Byrne PJ, et al. Barrett esophagus: prevalence of central adiposity, metabolic syndrome, and a proinflammatory state. Ann Surg. 2008;247(6):909-15. doi: 10.1097/SLA.0b013e3181612cac.

9. Tan CE, Chew SK, Tai ES. The metabolic syndrome: an Asian perspective. Inter Congr Series. 2004;1262:546-9. doi: 10.1016/j.ics.2003.12.089.

10. Lee S-W, Lien H-C, Chang C-S, Lee T-Y, Peng Y-C, Yeh H-Z. Association of metabolic syndrome with erosive esophagitis and Barrett's esophagus in a Chinese population. Journal of the Chinese Medical Association. 2017;80(1):15-8.

11. Healy LA, Ryan AM, Pidgeon G, Ravi N, Reynolds JV. Lack of differential pattern in central adiposity and metabolic syndrome in Barrett's esophagus and gastroesophageal reflux disease. Dis Esophagus. 2010;23(5):386-91.

12. Wani SB, Pondugula K, Bansal A, Rastogi A, Mathur S, Higbee A, et al. Metabolic syndrome is not a risk factor for Barrett's esophagus. Gastroenterology 2008; 134:A321.

13. Duggan C, Onstad L, Hardikar S, Blount PL, Reid BJ, Vaughan TL. Association between markers of obesity and progression from Barrett's esophagus to esophageal adenocarcinoma. Clin Gastroenterol Hepatol. 2013;11(8):934-43.

14. Drahos J, Ricker W, Parsons R, Pfeiffer RM, Warren JL, Cook MB. Metabolic syndrome increases risk of Barrett's esophagus in the absence of gastroesophageal reflux: An analysis of SEER-Medicare data. Journal of clinical gastroenterology. 2015;49(4):282.

15. Leggett CL, Nelsen EM, Tian J, Schleck CB, Zinsmeister AR, Dunagan KT, et al. Metabolic syndrome as a risk factor for Barrett esophagus: a populationbased case-control study. Mayo Clin Proc. 2013;88(2):157-65.

16. Thrift AP, Hilal J, El-Serag HB. Metabolic syndrome and the risk of Barrett's oesophagus in white males. Aliment Pharmacol Ther. 2015;41(11):1182-9.

17. Drahos J, Li L, Jick SS, Cook MB. Metabolic syndrome in relation to Barrett's esophagus and esophageal adenocarcinoma: Results from a large population-based case-control study in the Clinical Practice Research Datalink. Cancer Epidemiol. 2016;42:9-14.

18. Wu PC, Chen YH, Wu FZ, Lin KH, Hsu CL, Chen CS, et al. Risk factors for Barrett's esophagus in young adults who underwent upper gastrointestinal endoscopy in a health examination center. Therap Adv Gastroenterol. 2019;12:1756284819853115. 
19. Drahos J,Ricker W, Pfeiffer RM, Cook MB. Metabolic syndrome and risk of esophageal adenocarcinoma in elderly patients in the United States: An analysis of SEER-Medicare data. Cancer. 2017;123(4):657-665.

20. Kendall B, Macdonald G, Hayward N, Prins J, O'Brien S, Whiteman D, et al. Metabolic syndrome and the risk of Barrett's oesophagus. Journal of Gastroenterology and Hepatology. 2010;25(Supplement s3):A78-A.

21. Azami M, Jaafari Z, Masoumi M, Shohani M, Badfar G, Mahmudi L, et al. The etiology and prevalence of urinary tract infection and asymptomatic bacteriuria in pregnant women in Iran: a systematic review and Meta-analysis. BMC Urology. 2019;19(1):43.

22. Azami M, Moslemirad M, YektaKooshali MH, Rahmati S, Soleymani A, Shamloo MBB, et al. Workplace violence against Iranian nurses: a systematic review and meta-analysis. Violence and victims. 2018;33(6):1148-75.

23. Stroup DF, Berlin JA, Morton SC, Olkin I, Williamson GD, Rennie D, Moher D, Becker BJ, Sipe TA, Thacker SB. Meta-analysis of observational studies in epidemiology: a proposal for reporting. Meta-analysis Of Observational Studies in Epidemiology (MOOSE) group. JAMA. 2000; 283(15):2008-2012.

24. Shamseer L, Moher D, Clarke M, Ghersi D, Liberati A, Petticrew M, et al;PRISMA-P Group. PRISMA-P Group. Preferred reporting items for systematic review and meta-analysis protocols (PRISMA-P) 2015:elaboration and explanation. BMJ 2015;349:g7647.

25. Wells GA, Shea B, O'Connell D, Peterson J, Welch V, Losos M, et al. The Newcastle-Ottawa Scale (NOS) for assessing the quality of nonrandomized studies in meta-analyses. 2011, [cited 2012 Nov 25]. Available from:http://www.ohri.ca/programs/clinical_epidemiology/oxford.asp.

26. Higgins JPT, Green S. Cochrane Handbook for Systematic Reviews of Interventions Version 5.1.0. Available from: http://handbook.cochrane.org/.

27. Ades AE, Lu G, Higgins JP. The Interpretation of Random-Effects Meta-Analysis in Decision Models. Med Decis Making 2005;25(6):646-54.

28. Begg C. B., Mazumdar M. Operating characteristics of a rank correlation test for publication bias. Biometrics 1994; 50: 1088-1101.

29. Egger M., Davey Smith G., Schneider M., Minder C. Bias in meta-analysis detected by a simple, graphical test. BMJ 1997; 315: 629-634.

30. He Q, Li JD, Huang W, Zhu WC, Yang JQ. Metabolic syndrome is associated with increased risk of Barrett esophagus: A meta-analysis. Medicine (Baltimore). 2016;95(31):e4338.

31. Krishnamoorthi R, Singh S, Ragunathan K, Visrodia K, Wang KK, Katzka DA, et al. Factors Associated With Progression of Barrett's Esophagus: A Systematic Review and Meta-analysis. Clin Gastroenterol Hepatol. 2018;16(7):1046-1055.e8. doi: 10.1016/j.cgh.2017.11.044. Epub 2017 Dec 2

32. Beales IL, Dearman L, Vardi I, Loke Y. Reduced Risk of Barrett's Esophagus in Statin Users: Case-Control Study and Meta-Analysis. Dig Dis Sci. 2016;61(1):238-46.

33. Erőss B, Farkas N, Vincze Á, Tinusz B, Szapáry L, Garami A, et al. Helicobacter pylori infection reduces the risk of Barrett's esophagus: A meta-analysis and systematic review. Helicobacter. 2018;23(4):e12504. doi: 10.1111/hel.12504. Epub 2018 Jun 25.

34. Runge TM, Abrams JA, Shaheen NJ. Epidemiology of Barrett's Esophagus and Esophageal Adenocarcinoma. Gastroenterol Clin North Am. 2015;44(2):203-231. doi:10.1016/j.gtc.2015.02.001

35. Ding YE, Li Y, He XK, Sun LM. Impact of Barrett's esophagus surveillance on the prognosis of esophageal adenocarcinoma: A meta-analysis. J Dig Dis. 2018;19(12):737-744.

36. Singh S, Sharma AN, Murad MH, Buttar NS, El-Serag HB, Katzka DA, et al. Central adiposity is associated with increased risk of esophageal inflammation, metaplasia, and adenocarcinoma: a systematic review and meta-analysis. Clin Gastroenterol Hepatol. 2013;11(11):1399-1412 e7. doi: 10.1016/j.cgh.2013.05.009.

37. Barak N, Ehrenpreis ED, Harrison JR, Sitrin MD. Gastro-oesophageal reflux disease in obesity: pathophysiological and therapeutic considerations. Obes Rev. 2002;3(1):9-15.

38. Wu P, Ma L, Dai GX, Chen Y, Tong YL, Wang C, et al. The association of metabolic syndrome with reflux esophagitis: a case-control study. Neurogastroenterol Motil. 2011;23(11):989-94. doi: 10.1111/j.1365-2982.2011.01786.x.

39. Long E, Beales IL. The role of obesity in oesophageal cancer development. Therap Adv Gastroenterol 2014;7:247-68.

40. Nguyen-Duy TB, Nichaman MZ, Church TS, Blair SN, Ross R. Visceral fat and liver fat are independent predictors of metabolic risk factors in men. Am J Physiol Endocrinol Metab 2003; 284: E1065-E1071

41. Moro E, Gallina P, Pais M, Cazzolato G, Alessandrini P, Bittolo-Bon G. Hypertriglyceridemia is associated with increased insulin resistance in subjects with normal glucose tolerance: evaluation in a large cohort of subjects assessed with the 1999 World Health Organization criteria for the classification of diabetes. Metabolism 2003; 52: 616-619

42. Labenz J, Blum AL, Bayerdorffer E, Meining A, Stolte M, Borsch G. Curing Helicobacter pylori infection in patients with duodenal ulcer may provoke reflux esophagitis. Gastroenterology 1997; 112: 1442-1447

43. Tsukada K, Katoh H, Miyazaki T, Fukuchi M, Kuwano H, Kimura H, Fukai Y, Inose T, Motojima T, Toda N, Yamada S. Factors associated with the development of reflux esophagitis after Helicobacter pylori eradication. Dig Dis Sci 2006; 51: 539-542

44. Laurila A, Bloigu A, Nayha S, Hassi J, Leinonen M, Saikku P. Association of Helicobacter pylori infection with elevated serum lipids. Atherosclerosis 1999; 142: $207-210$

45. Gudlaugsdottir S, Verschuren W, Dees J, Stijnen T, Wilson J. Hypertension is frequently present in patients with reflux esophagitis or Barrett's esophagus but not in those with non-ulcer dyspepsia. Eur J Intern Med. 2002;13(6):369.

46. Furuta K, Adachi K, Arima N, Yagi J, Tanaka S, Miyaoka Y, et al. Study of arteriosclerosis in patients with hiatal hernia and reflux esophagitis. J Gastroenterol Hepatol. 2007;22:1732-6.

\section{Tables}


Table 1: Summary of characteristics in studies into a meta-analysis

\begin{tabular}{|c|c|c|c|c|c|c|c|c|c|c|c|c|c|}
\hline \multirow[t]{3}{*}{ Ref. } & \multirow{3}{*}{$\begin{array}{c}\text { First } \\
\text { author, } \\
\text { Published } \\
\text { Year }\end{array}$} & \multirow[t]{3}{*}{ Design } & \multirow{3}{*}{$\begin{array}{l}\text { Year } \\
\text { of } \\
\text { study }\end{array}$} & \multirow[t]{3}{*}{ Place } & \multirow[t]{3}{*}{ Study setting } & \multirow{3}{*}{$\begin{array}{l}\text { Special } \\
\text { groups }\end{array}$} & \multirow{3}{*}{$\begin{array}{l}\text { Controls } \\
\text { groups }\end{array}$} & \multirow{3}{*}{$\begin{array}{l}\text { criteria } \\
\text { for MetS }\end{array}$} & \multicolumn{5}{|c|}{ Sample size } \\
\hline & & & & & & & & & \multirow[t]{2}{*}{ All } & \multicolumn{2}{|r|}{ Case } & \multicolumn{2}{|r|}{ Control } \\
\hline & & & & & & & & & & All & $\mathrm{M}, \mathrm{F}$ & All & $\mathrm{M}, \mathrm{I}$ \\
\hline 10 & $\begin{array}{l}\text { Lee SW, } \\
2017\end{array}$ & $\begin{array}{l}\text { Cross- } \\
\text { sectional }\end{array}$ & $\begin{array}{l}2006- \\
9\end{array}$ & Taiwan & Population_based & & $\begin{array}{l}\text { Endoscopy } \\
\text { control }\end{array}$ & IDF & 6594 & 95 & $61: 34$ & 6499 & $3447: 3 C$ \\
\hline 11 & $\begin{array}{l}\text { Healy } \\
\text { L.A, } 2010\end{array}$ & $\begin{array}{l}\text { Case- } \\
\text { control }\end{array}$ & 2003 & Ireland & Hospital_based & - & $\begin{array}{l}\text { Control with } \\
\text { reflux } \\
\text { symptoms }\end{array}$ & IDF & 231 & 118 & $79: 39$ & 113 & $67: 46$ \\
\hline 12 & $\begin{array}{l}\text { Wani SB, } \\
2008\end{array}$ & $\begin{array}{l}\text { Case- } \\
\text { control }\end{array}$ & NR & USA & Hospital_based & $\begin{array}{l}93.2 \% \\
\text { Caucasians }\end{array}$ & $\begin{array}{l}\text { Control with } \\
\text { reflux } \\
\text { symptoms }\end{array}$ & $\begin{array}{l}\text { Not } \\
\text { mentioned }\end{array}$ & 309 & 103 & & 206 & \\
\hline 13 & $\begin{array}{l}\text { Duggan } \\
\mathrm{C}, 2013\end{array}$ & Cohort & $\begin{array}{l}1995- \\
2009\end{array}$ & USA & Hospital_based & $\begin{array}{l}96.4 \% \\
\text { White }\end{array}$ & BE baseline & IDF & 388 & & & & \\
\hline 14 & $\begin{array}{l}\text { Drahos J, } \\
2015\end{array}$ & $\begin{array}{l}\text { Cross- } \\
\text { sectional }\end{array}$ & 2009 & USA & Population_based & $\begin{array}{l}87.4 \% \\
\text { White }\end{array}$ & $\begin{array}{l}\text { Endoscopy } \\
\text { control }\end{array}$ & $\begin{array}{l}\text { NCEP- } \\
\text { ATP III }\end{array}$ & 8792 & 2198 & $1150: 1048$ & 6594 & $\overline{3450: 31}$ \\
\hline 14 & $\begin{array}{l}\text { Drahos J, } \\
2015\end{array}$ & $\begin{array}{l}\text { Cross- } \\
\text { sectional }\end{array}$ & 2009 & USA & Population_based & $\begin{array}{l}85.3 \% \\
\text { White }\end{array}$ & $\begin{array}{l}\text { Endoscopy } \\
\text { control }\end{array}$ & $\begin{array}{l}\text { NCEP- } \\
\text { ATP III }\end{array}$ & 8170 & 2198 & $1150: 1048$ & 5972 & $3036: 2 \mathrm{C}$ \\
\hline 15 & $\begin{array}{l}\text { Leggett } \\
\text { CL, } 2013\end{array}$ & $\begin{array}{l}\text { Case- } \\
\text { control }\end{array}$ & $\begin{array}{l}\text { 1999- } \\
2006\end{array}$ & $\overline{\mathrm{USA}}$ & Population_based & $\begin{array}{l}96.4 \% \\
\text { Caucasians }\end{array}$ & $\begin{array}{l}\text { Control } \\
\text { without } \\
\text { reflux } \\
\text { symptoms }\end{array}$ & $\begin{array}{l}\text { IDF and } \\
\text { WHO }\end{array}$ & 206 & 103 & $70: 33$ & 103 & $70: 33$ \\
\hline 15 & $\begin{array}{l}\text { Leggett } \\
\text { CL, } 2013\end{array}$ & $\begin{array}{l}\text { Case- } \\
\text { control }\end{array}$ & $\begin{array}{l}1999- \\
2006\end{array}$ & $\overline{U S A}$ & Population_based & $\begin{array}{l}96.4 \% \\
\text { Caucasians }\end{array}$ & $\begin{array}{l}\text { Control with } \\
\text { reflux } \\
\text { symptoms }\end{array}$ & $\begin{array}{l}\text { IDF and } \\
\text { WHO }\end{array}$ & 206 & 103 & $70: 33$ & 103 & $70: 33$ \\
\hline 16 & $\begin{array}{l}\text { Thrift AP, } \\
2015\end{array}$ & $\begin{array}{l}\text { Case- } \\
\text { control }\end{array}$ & $\begin{array}{l}2008- \\
2011\end{array}$ & $\overline{\mathrm{USA}}$ & Hospital_based & $\begin{array}{l}100 \% \\
\text { White man }\end{array}$ & $\begin{array}{l}\text { Colonoscopy } \\
\text { control }\end{array}$ & $\begin{array}{l}\text { NCEP- } \\
\text { ATP III }\end{array}$ & 453 & 244 & & 209 & \\
\hline 16 & $\begin{array}{l}\text { Thrift AP, } \\
2015\end{array}$ & $\begin{array}{l}\text { Case- } \\
\text { control }\end{array}$ & $\begin{array}{l}2008- \\
2011\end{array}$ & $\overline{U S A}$ & Hospital_based & $\begin{array}{l}100 \% \\
\text { White man }\end{array}$ & $\begin{array}{l}\text { Endoscopy } \\
\text { control }\end{array}$ & $\begin{array}{l}\text { NCEP- } \\
\text { ATP III }\end{array}$ & 859 & 244 & & 615 & \\
\hline 17 & $\begin{array}{l}\text { Drahos J, } \\
2016\end{array}$ & $\begin{array}{l}\text { Cross- } \\
\text { sectional }\end{array}$ & $\begin{array}{l}1992- \\
2012\end{array}$ & $\begin{array}{l}\text { United } \\
\text { Kingdom }\end{array}$ & Population_based & & $\begin{array}{l}\text { Endoscopy } \\
\text { control }\end{array}$ & $\begin{array}{l}\text { NCEP- } \\
\text { ATP III }\end{array}$ & 60382 & 10215 & 6399:3816 & 50167 & $\overline{31375: 1}$ \\
\hline 18 & $\begin{array}{l}\text { Wu P-C, } \\
2019\end{array}$ & $\begin{array}{l}\text { Cross- } \\
\text { sectional }\end{array}$ & $\begin{array}{l}2016- \\
2018\end{array}$ & $\begin{array}{l}\text { South } \\
\text { Korea }\end{array}$ & Population_based & & $\begin{array}{l}\text { Endoscopy } \\
\text { control }\end{array}$ & $\overline{\text { IDF }}$ & 4943 & 88 & $66: 22$ & 4855 & $2475: 23$ \\
\hline 19 & $\begin{array}{l}\text { Drahos J, } \\
2017\end{array}$ & $\begin{array}{l}\text { Cross- } \\
\text { sectional }\end{array}$ & $\begin{array}{l}2003- \\
2009\end{array}$ & $\overline{U S A}$ & Population_based & & $\begin{array}{l}\text { Endoscopy } \\
\text { control }\end{array}$ & $\begin{array}{l}\text { NCEP- } \\
\text { ATP III }\end{array}$ & 16410 & 575 & & 15835 & \\
\hline 20 & $\begin{array}{l}\text { Kendall } \\
\text { B, } 2010\end{array}$ & $\begin{array}{l}\text { Case- } \\
\text { control }\end{array}$ & $\begin{array}{l}2003- \\
6\end{array}$ & Australia & Population_based & & $\begin{array}{l}\text { Endoscopy } \\
\text { control }\end{array}$ & $\begin{array}{l}\text { Not } \\
\text { mentioned }\end{array}$ & 473 & 236 & & 237 & \\
\hline
\end{tabular}

MetS: Metabolic Syndrome; M,F: Male, female; QS: Quality Score; OR: Odds Ratio; CI: Confidence Interval; IDF: International Diabetes Federation; WHO: world Health Organization; NCEP ATP III: National Cholesterol Education Program Adult Treatment Panel III: LA: Los Angeles classification; NR: Not Reported. * was calculated.

\section{Figures}




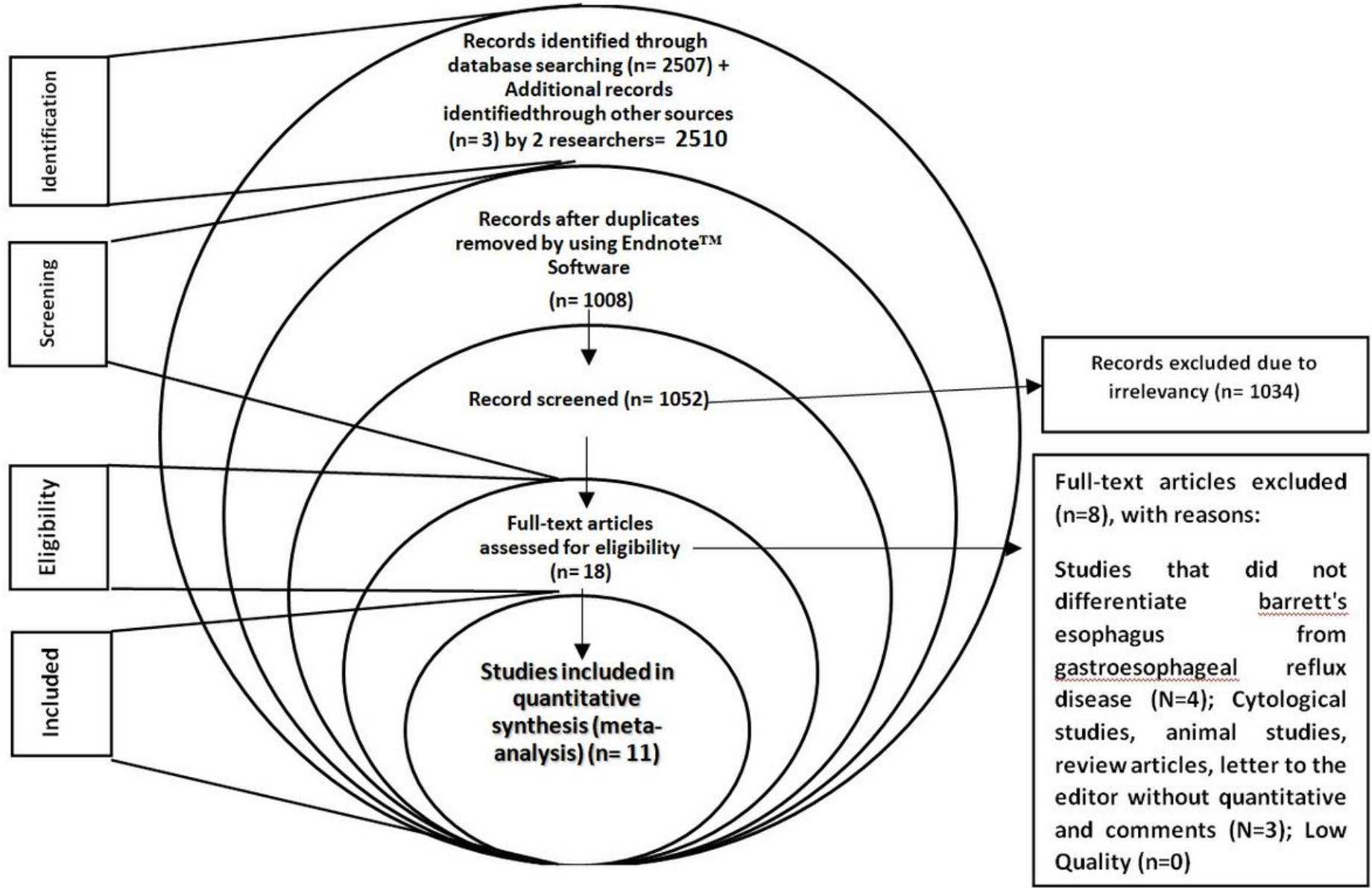

Figure 1

The studies selection process for meta-analysis. 


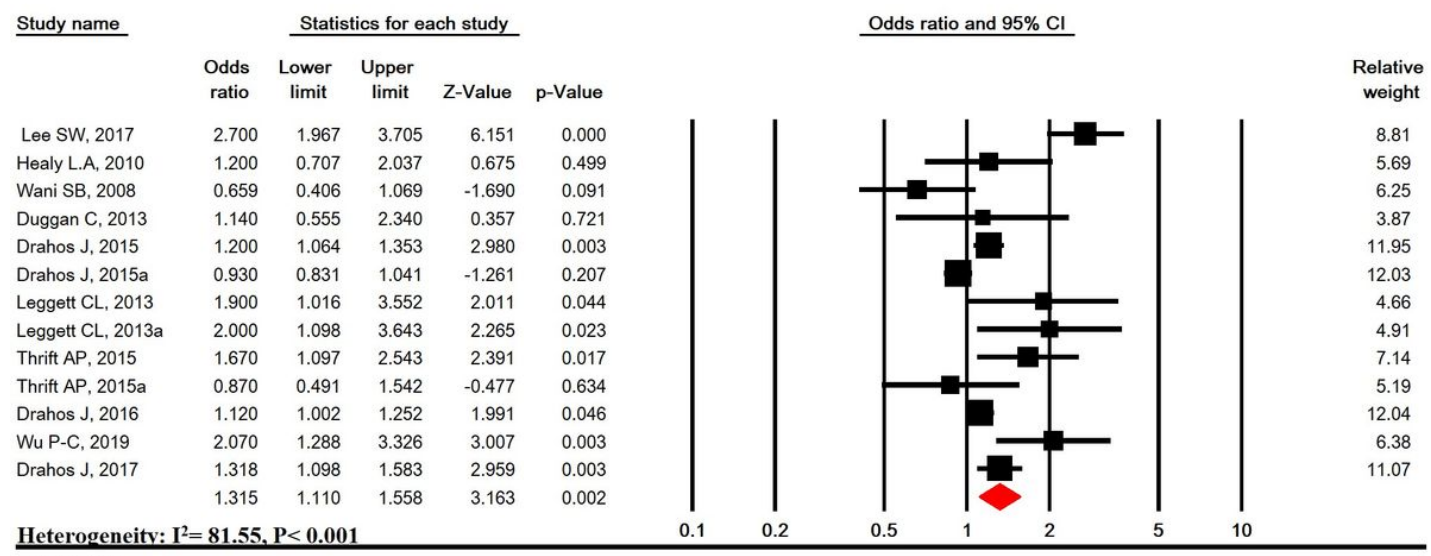

\section{Meta Analysis}

B

\begin{tabular}{|c|c|c|c|c|c|c|c|c|c|c|}
\hline \multirow[t]{2}{*}{ Study name } & \multirow[b]{2}{*}{ Point } & \multicolumn{3}{|c|}{ Statistics with study removed } & \multirow[b]{2}{*}{ p-Value } & & & \multirow[t]{2}{*}{ Odds ratio $(95 \% \mathrm{Cl})$} & \multirow[t]{2}{*}{ with study removed } & \\
\hline & & $\begin{array}{c}\text { Lower } \\
\text { limit }\end{array}$ & $\begin{array}{c}\text { Upper } \\
\text { limit }\end{array}$ & Z-Value & & & & & & \\
\hline Lee SW, 2017 & 1.256 & 1.086 & 1.452 & 3.078 & 0.002 & & & I & 1 & 1 \\
\hline Healy L.A, 2010 & 1.364 & 1.146 & 1.623 & 3.491 & 0.000 & & & & & \\
\hline Wani SB, 2008 & 1.413 & 1.193 & 1.674 & 4.010 & 0.000 & & & & & \\
\hline Duggan C, 2013 & 1.363 & 1.148 & 1.619 & 3.527 & 0.000 & & & & & \\
\hline Drahos J, 2015 & 1.380 & 1.131 & 1.684 & 3.170 & 0.002 & & & & & \\
\hline Drahos J, 2015a & 1.417 & 1.191 & 1.685 & 3.932 & 0.000 & & & & & \\
\hline Leggett CL, 2013 & 1.332 & 1.123 & 1.580 & 3.296 & 0.001 & & & & & \\
\hline Leggett CL, 2013a & 1.328 & 1.120 & 1.574 & 3.266 & 0.001 & & & & & \\
\hline Thrift AP, 2015 & 1.333 & 1.121 & 1.585 & 3.257 & 0.001 & & & & & \\
\hline Thrift AP, 2015a & 1.385 & 1.166 & 1.646 & 3.701 & 0.000 & & & & & \\
\hline Drahos J, 2016 & 1.391 & 1.138 & 1.701 & 3.216 & 0.001 & & & & & \\
\hline Wu P-C, 2019 & 1.316 & 1.112 & 1.559 & 3.186 & 0.001 & & & & & \\
\hline Drahos J, 2017 & 1.361 & 1.131 & 1.637 & 3.268 & 0.001 & & & & & \\
\hline \multirow[t]{3}{*}{ Kendall B, 2010} & 1.315 & 1.110 & 1.558 & 3.163 & 0.002 & & & & & \\
\hline & 1.354 & 1.145 & 1.600 & 3.544 & 0.000 & & & | & & | \\
\hline & & & & & & 0.1 & 0.2 & 0.5 & 2 & 10 \\
\hline
\end{tabular}

Meta Analysis

Figure 2

Meta-analysis (A) and sensitivity analysis (B) for the association between metabolic syndrome and increased risk of barrett's esophagus. 
$\underline{\mathbf{A}}$

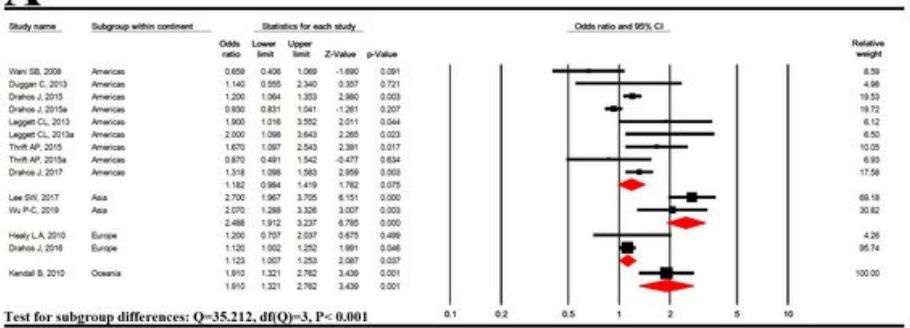

Test for subyroup differences: $\mathrm{Q}-35.212$, df 0 ) $-3, \mathrm{P}<0.201$

\section{B}
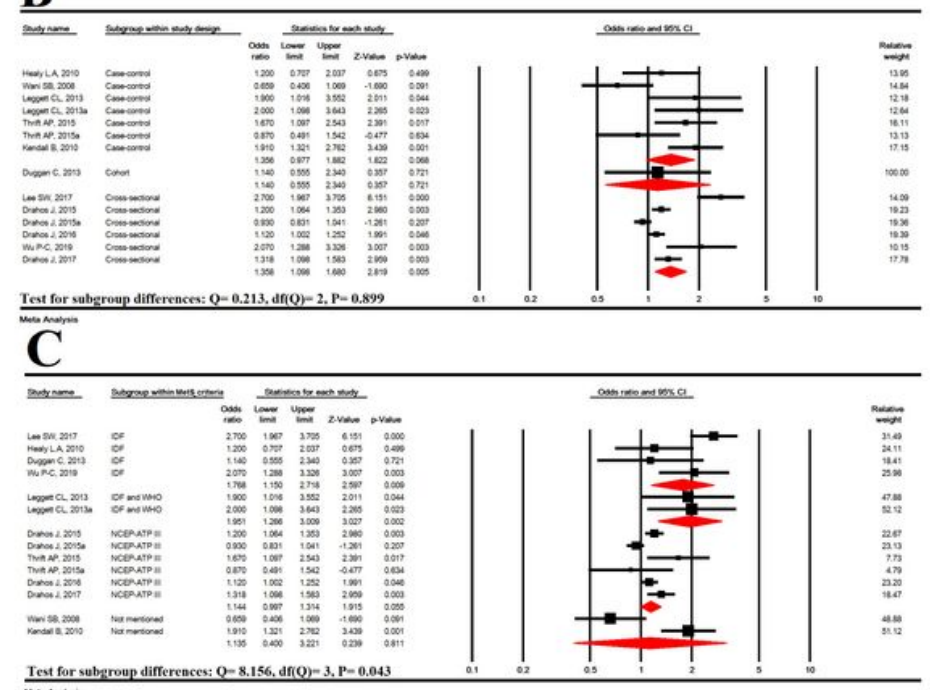

D

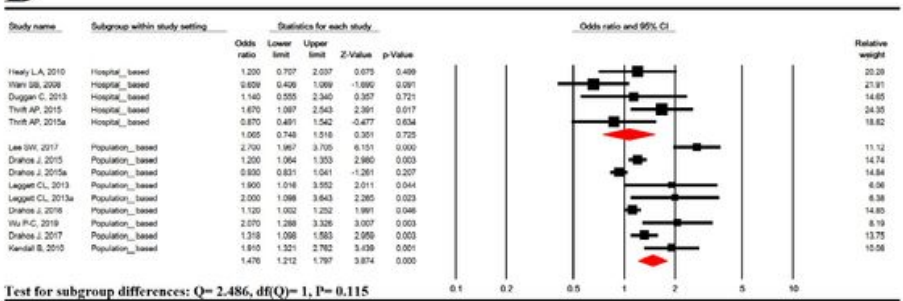

E

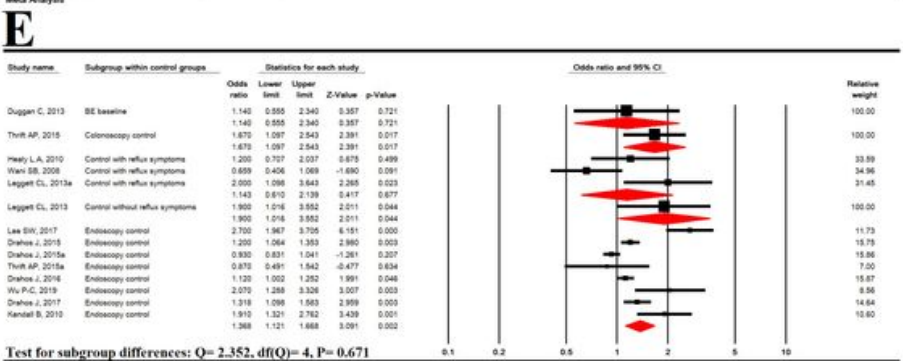

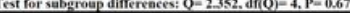

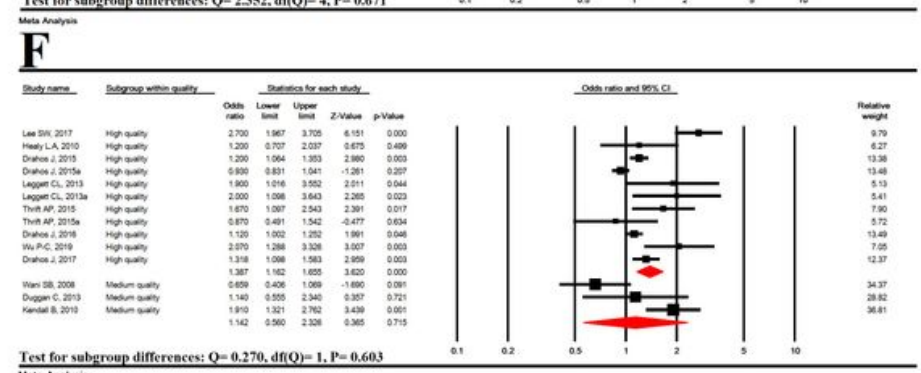

Figure 3

Subgroup analysis based on continents (A), study design (B), MetS diagnostic criteria (C), study setting (D) and control groups (E), study quality (F)

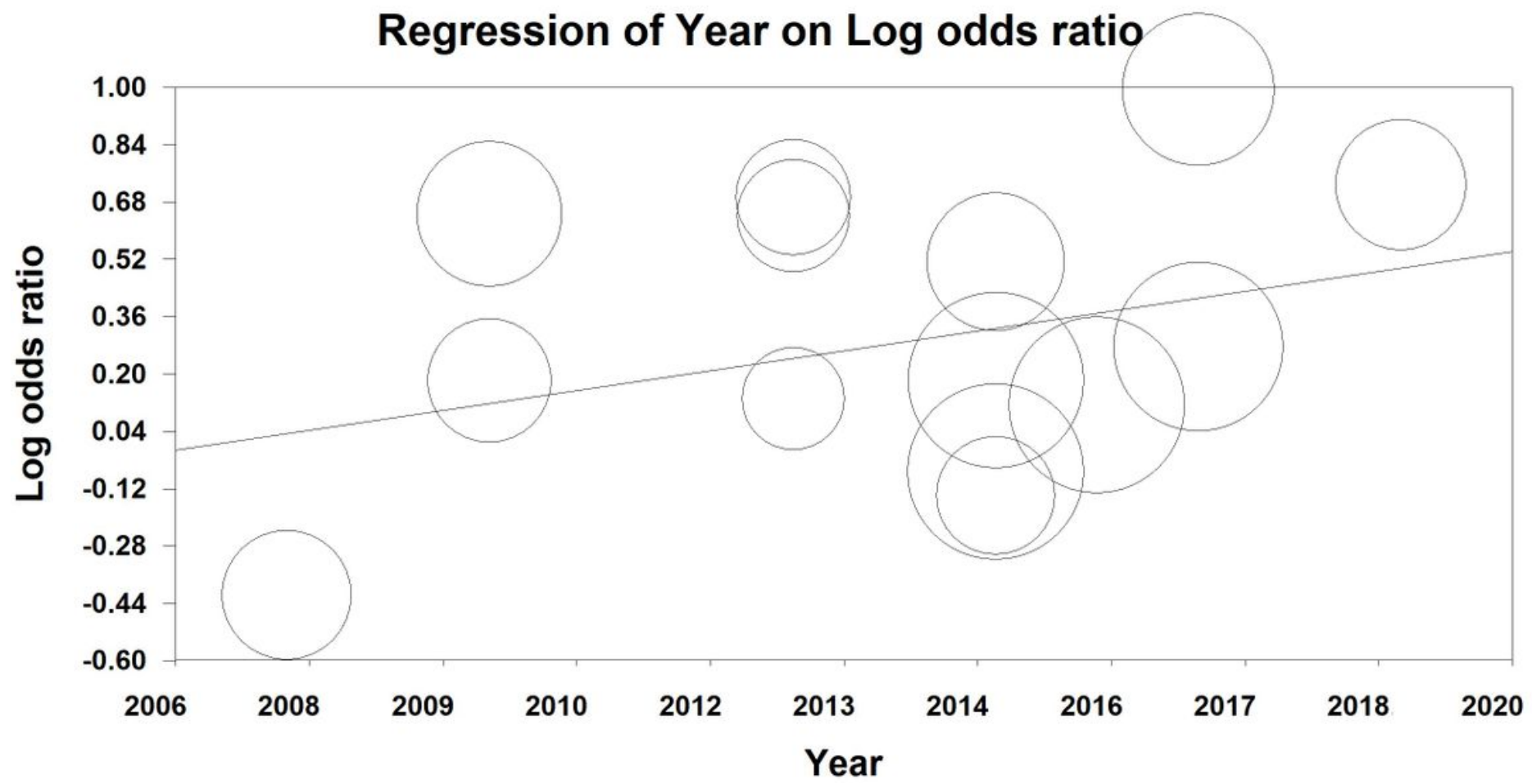

Figure 4

Meta-regression based on published year 


\section{Funnel Plot of Standard Error by Log odds ratio}

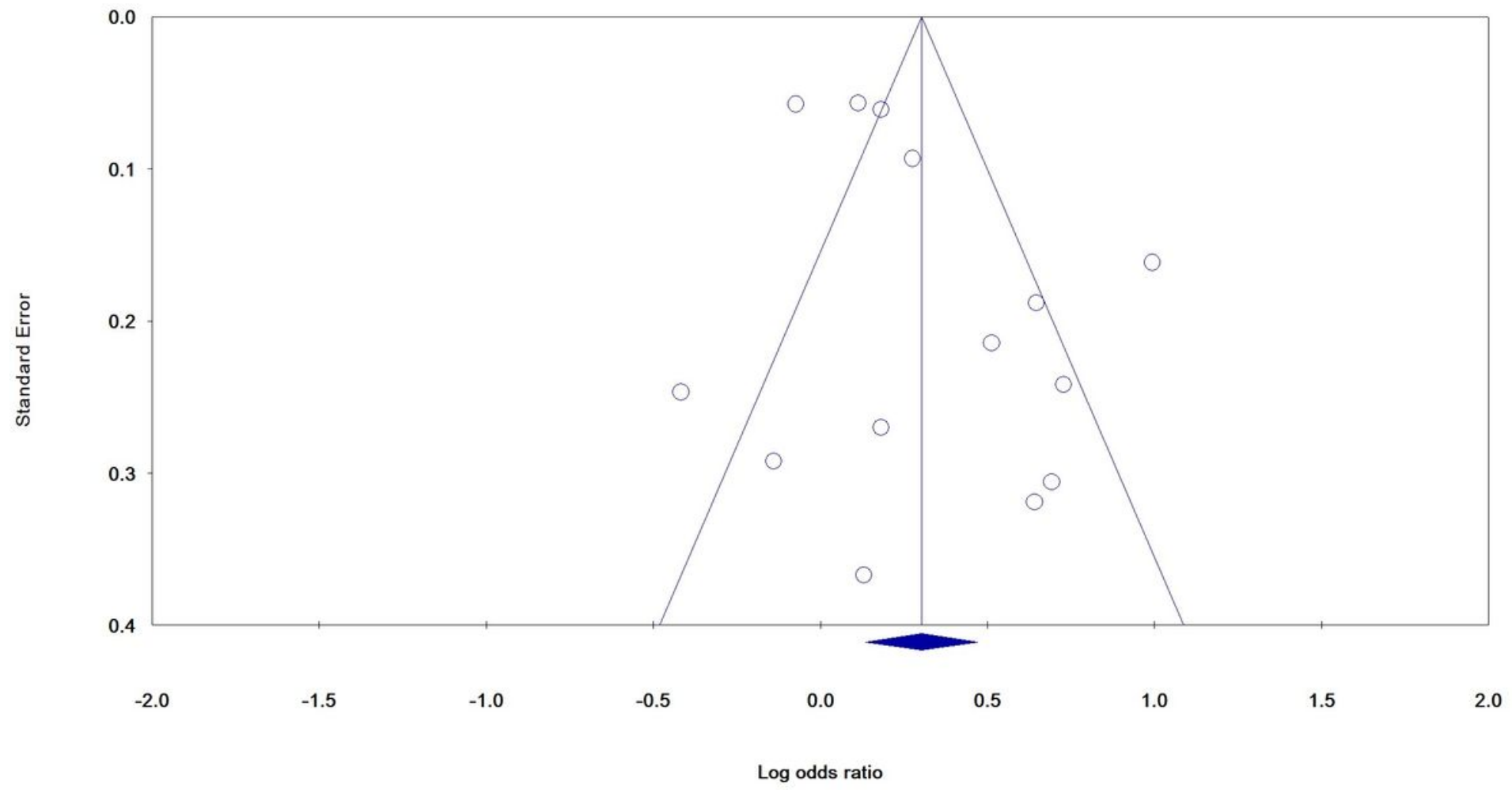

Figure 5

Publication bias

\section{Supplementary Files}

This is a list of supplementary files associated with this preprint. Click to download.

- S1FileReportingguidelineschecklist.DOC 